\title{
FAKTOR-FAKTOR YANG MEMPENGARUHI PENGEMBALIAN KREDIT PROGRAM BANTUAN LANGSUNG MASYARAKAT PENGEMBANGAN USAHA AGRIBISNIS PEDESAAN (BLM-PUAP) DI KABUPATEN INDRAGIRI HILIR
}

\author{
Yeni Afiza \\ Program Studi Agribisnis Fakultas Pertanian UNISI \\ Email : yeni_afiza@yahoo.co.id
}

\begin{abstract}
ABSTRAK
PUAP merupakan bantuan pemerintah untuk masyarakat pedesaan dengan menyalurkan bantuan modal usahatani yang bersifat stimulan. Kemacetan Pengembalian Kredit BLM-PUAP di Kabupaten Indragiri Hilir cukup tinggi. Penentuan sampel dilakukan dengan metode stratified random sampling dengan melihat Non Performing Loan anggota Poktan. Analisis yang digunakan untuk mengetahui faktor-faktor pengembalian kredit program BLM-PUAP ialah model regresi linear berganda. Hasil penelitian memperlihatkan bahwa faktor yang berpengaruh nyata terhadap tunggakan kredit dari sisi anggota adalah jarak tempat tinggal dengan kantor BLM-PUAP, pengaruh orang lain yang tidak membayar kredit, sikap petani tidak mau bayar kredit dan pekerjaan utama. Sistem kredit kelompok hanya dimanfaatkan dalam pengambilan dana kredit PUAP, dalam penagihan pembayaran angsuran dilakukan secara individu oleh masing-masing anggota kepada kelompok masing-masing.
\end{abstract}

Kata kunci : faktor-faktor pengembalian kredit

\section{PENDAHULUAN}

Menurut Mosher (1987), kredit merupakan salah satu faktor pelancar pembangunan pertanian. Untuk meningkatkan hasil produksi, petani membutuhkan modal yang besar agar dapat menggunakan teknologi usahatani secara optimal. Namun, adopsi teknologi pada umumnya relatif mahal dan petani kecil tidak mampu untuk membiayai teknologi tersebut, akibatnya pemanfaatan teknologi pertanian sangat rendah.

Modal merupakan salah satu faktor internal yang penting dalam pelaksanaan usahatani yang dijalankan oleh petani. Menurut
Soetriono dalam Supanggih dan Slamet (2013), petani kecil atau lebih dikenal sebagai petani gurem mendapatkan modal biasanya dari penyisihan pendapatan usahatani sebelumnya. Kondisi yang masih menghadapi risk of uncertainty, maka petani berada pada posisi yang kurang menguntungkan, ditambah beban kebutuhan keluarga seharihari. Keadaan ini yang dapat menyebabkan petani terjerat pada sistem peminjaman yang merugikan petani. Tidak jarang petani melakukan peminjaman modal usahatani keberbagai tempat. Peminjaman modal usahatani dilakukan ke lembaga keuangan formal (bank, koperasi simpan 
pinjam, kelompok tani, KUD) ataupun nonformal (rentenir).

Menutupi kekurangan modal, petani umumnya mengajukan pinjaman ke lembaga pembiayaan di sekitar tempat tinggal mereka, baik formal maupun informal. Kredit formal dapat berupa kredit program dan kredit non program (kredit komersial). Kredit program umumnya terkait dengan pelaksanaan program pemerintah, misalnya KKP. Contoh kelembagaan kredit formal antara lain bank, koperasi dan pegadaian yang menerapkan persyaratan cukup ketat dalam pelayanan peminjaman. Sementara pada kredit informal, pada umumnya tidak memerlukan persyaratan yang rumit, misalnya keharusan adanya agunan.

Menurut Supriatna (2009), melalui kebijakan pemerintah, berbagai lembaga permodalan berbunga rendah telah berkembang ditingkat petani, seperti BRI Unit Desa, Bank Perkreditan Rakyat (BPR), pegadaian dan koperasi. Dengan adanya berbagai lembaga pembiayaan tersebut, diharapkan kebutuhan petani akan kredit berbunga rendah dapat terpenuhi sehingga tidak perlu meminjamnya dari pelepas uang (money lender) yang menetapkan suku bunga tinggi. Namun, kenyataan di lapangan menunjukkan, sebagian besar petani masih lebih akrab dengan sumber pembiayaan informal seperti pedagang sarana produksi, pelepas uang atau penggilingan padi.

Permasalahan yang dihadapi
dalam permodalan pertanian
berkaitan langsung $\begin{array}{r}\text { dengan } \\ \text { kelembagaan selama ini yaitu }\end{array}$
lemahnya organisasi tani, sistem dan
prosedur penyaluran kredit yang

rumit, birokratis dan kurang memperhatikan kondisi lingkungan sosial budaya pedesaan, sehingga sulit menyentuh kepentingan petani yang sebenarnya. Menurut Syahyuti (2007), kemampuan petani dalam mengakses sumber-sumber permodalan sangat terbatas karena lembaga keuangan perbankan dan non-perbankan menerapkan prinsip 5-C (Character, Collateral, Capacity, Capital dan Condition) dalam menilai usaha pertanian yang tidak semua persyaratan yang diminta dapat dipenuhi oleh petani. Secara umum, usaha disektor pertanian masih dianggap beresiko tinggi, sedangkan skim kredit masih terbatas untuk usaha produksi, belum menyentuh kegiatan pra dan pasca produksi dan sampai saat ini belum berkembangnya lembaga penjamin serta belum adanya lembaga keuangan khusus yang menangani sektor pertanian.

Salah satu usaha pemerintah dalam menangani permasalahan permodalan tersebut dengan mengucurkan Bantuan Langsung Masyarakat (BLM) yang tertuang dalam peraturan menteri pertanian nomor 11/Permentan/OT.140/3/2011 tentang kriteria penentuan calon lokasi bahwa Desa / Kelurahan calon lokasi PUAP adalah (1) Desa mempunyai potensi pertanian, diutamakan desa miskin, (2) Memiliki Gapoktan, (3) Belum memperoleh dana BLM-PUAP. Calon penerima dana BLM-PUAP harus berada pada desa calon lokasi PUAP yang memenuhi kriteria (1) Memiliki Sumber Daya Manusia (SDM) untuk mengelola usaha agribisnis (2) Mempunyai kepengurusan yang aktif dan dikelola oleh petani (3) Pengurus Gapoktan 
adalah petani dan bukan aparat Desa/Kelurahan.

Menurut Martiana (2012), beberapa faktor penyebab terjadinya kemacetan dalam pengembalian pinjaman dana BLM-PUAP yaitu : 1) pemahaman yang salah tentang dana BLM-PUAP yang diberikan pemerintah kepada petani, sebagian besar petani menganggap bahwa dana BLM-PUAP tidak perlu dikembalikan, karena dana BLMPUAP adalah dana bantuan pemerintah. 2) kurangnya kepercayaan petani anggota Gapoktan kepada pengurus Gapoktan. 3) kurangnya keteladanan dari pengurus Gapoktan dalam pengembalian pinjaman dana BLMPUAP. 4) denda pinjaman sudah membengkak karena sudah lama tidak dikembalikan. 5) kurangnya pengawasan dari pihak pemerintah (Dinas Pertanian) berkaitan dengan jalannya program PUAP. 6) kurangnya kegiatan penyuluhan tentang meningkatkan usahatani. 7) tidak adanya aturan atau sanksi tegas yang menjamin dana BLM-PUAP diberdayakan secara optimal.

Program Bantuan Langsung Masyarakat Pengembangan Usaha Agribisnis Pedesaan (BLM-PUAP) di Kabupaten Indragiri Hilir yang digulirkan pemerintah dalam bentuk peminjaman modal lunak yaitu sebesar Rp. 100.000.000,00 per Gapoktannya, diharapkan mampu mengatasi masalah yang terkait dengan kesejahteraan petani khususnya dipedesaan.

Pelaksanaan program BLMPUAP yang dilakukan pemerintah dengan memberikan bantuan berupa dana kepada masyarakat ini tentunya tidak terlepas dari adanya kredit macet. Karena mereka beranggapan bahwa dana BLM-PUAP ini merupakan bantuan dana hibah yang diberikan pemerintah kepada petani, padahal banyak diantara petani tersebut sebenarnya mampu untuk membayar cicilan kreditnya. Kemudian ada juga kredit macet ini memang ketidakmampuan petani itu sendiri, selain itu juga dikarenakan adanya pengaruh orang lain yang tidak membayar kredit. Hal ini tentunya berakibat pada terhambatnya perguliran dana. Tujuan penelitian ini adalah menganalisis faktor-faktor apa saja yang mempengaruhi pengembalian kredit.

\section{TINJAUAN PUSTAKA}

\subsection{Perkembangan Kelembagaan Pembiayaan Pedesaan}

Program penguatan modal adalah salah satu cara yang dapat membantu mengatasi keterbatasan permodalan petani dari pemerintah yang diawali dengan kredit BIMAS yang diimplementasikan pada tahun 1967/1970. Kondisi ini kemudian berkembang seiring dengan perkembangan dan kebutuhan di lapang, diantaranya menjadi Program Kredit Usaha Tani (KUT) pada tahun 1985. Pada tahun 2000 pemerintah mengaplikasikan melalui program Kredit Ketahanan Pangan (KKP), yang dilanjutkan dengan Kredit Ketahanan Pangan dan Energi (KKPE) sebagai penyempurnaan dari KKP, Proyek Peningkatan Pendapatan Petani/Nelayan Kecil (P4K), Lembaga Usaha Kelompok (PMUK), Kredit Usaha Mandiri (KUM), Skim Pelayanan Pembiayaan Pertanian (SP3), Kredit Usaha Perbibitan Sapi (KUPS), dan Kredit Usaha Rakyat (KUR). Program-program tersebut 
difokuskan untuk mendorong produktivitas pangan, utamanya pembiayaan usahatani padi.

Sejak tahun 2003, pemerintah juga mengimplementasikan program Penguatan Modal Lembaga Usaha Ekonomi Pedesaan (DPM LUEP) yang mempunyai tujuan untuk melindungi petani padi dengan cara membeli gabah petani sesuai dengan HPP (Harga Pembelian Pemerintah). Dalam pelaksanaannya, DPM LUEP bekerjasama dengan BULOG. Pelaksanaan kegiatan DPM LUEP di Kabupaten Ngawi Jawa Timur menurut Ashari (2009), mempunyai kinerja baik namun sebagai instrumen kebijakan harga wilayah masih belum sesuai dengan harapan, karena harga jual gabah petani masih tetap dibawah HPP.

Pada tahun 2008, Kementrian Pertanian melaksanakan Program PUAP sebagai program prioritas yang dilaksanakan secara integritas dengan kegiatan Kementrian/Lembaga ini dibawah payung Program Nasional Pemberdayaan Masyarakat (PNPM) Mandiri. Dapat didefinisikan bahwa PUAP adalah bantuan pemerintah untuk masyarakat pedesaan dengan menyalurkan bantuan modal usahatani yang bersifat stimulan. Penyaluran dana bantuan setiap tahun sebesar Rp. 100 juta per Gapoktan di 10.000 desa yang tersebar di 33 provinsi. Bantuan modal ini yang akhirnya disebut dana Bantuan Langsung Masyarakat (BLM) PUAP. Salah satu tujuan program PUAP ini ialah meningkatkan fungsi kelembagaan ekonomi petani menjadi jejaring atau mitra lembaga keuangan dalam rangka akses permodalan (Kementrian Pertanian, 2010).
Sebagai

program pemberdayaan, PUAP tahun 2010 merupakan tahun transformasi bagi Gapoktan penerima PUAP 2008 agar dapat menjadi kelembagaan keuangan mikro. Gapoktan penerima dana PUAP harus dapat mengelola dana melalui perguliran dan penambahan dan keswadayaan, sehingga dapat berfungsi sebagai Lembaga Keuangan Mikro Agribisnis (LKM-A) pada tahun ke3.

\subsection{Prinsip-prinsip Pemberian Kredit}

Menurut Kashmir (2003), dalam melakukan penilaian kriteriakriteria serta aspek penilainnya tetap sama. Begitu pula dengan ukuranukuran yang ditetapkan sudah menjadi standar penilaian setiap bank. Biasanya kriteria penilaian yang umum dan harus dilakukan oleh baik untuk mendapatkan nasabah yang benar-benar layak untuk diberikan, dilakukan dengan analisis 5 C. Penilaian dengan analisis $5 \mathrm{C}$ adalah sebagai berikut :

a. Character

Character merupakan sifat atau watak seseorang. Sifat atau watak dari orang-orang yang akan diberikan kredit benar-benar harus dapat dipercaya. Untuk membaca watak atau sifat dari calon debitur dapat dilihat dari latar belakang si nasabah, baik yang bersifat latar belakang pekerjaan maupun yang bersifat pribadi seperti cara hidup atau gaya hidup yang dianutnya, keadaan keluarga, hobi dan jiwa sosial. Dari sifat dan watak ini dapat dijadikan suatu ukuran tentang kemauan nasabah untuk membayar.

b. Capacity 
Capacity adalah analisis untuk mengetahui kemampuan nasabah dalam membayar kredit. Dari penilaian ini terlihat kemampuan nasabah dalam mengelola bisnis. Kemampuan ini dihubungkan dengan latar belakang pendidikan dan pengalamannya selama ini dalam mengelola usahanya, sehingga akan terlihat kemampuannya dalam mengembalikan kredit yang disalurkan. Capacity sering juga disebutdengan nama capability.

c. Capital

Untuk melihat penggunaan modal apakah efektif atau tidak, dapat dilihat dari laporan keuangan (neraca dan laporan rugi laba) yang disajikan dengan melakukan pengukuran seperti dari segi likuiditas dan solvabilitasnya, rentabilitas dan ukuran lainnya. Analisis capital juga harus menganalisis dari sumber mana saja modal yang ada sekarang ini, termasuk persentase modal yang digunakan untuk membiayai proyek yang akan dijalankan, berapa modal sendiri dan berapa modal pinjaman.

d. Condition

Dalam menilai kredit hendaknya juga dinilai kondisi ekonomi, sosial dan politik yang ada sekarang dan prediksi untuk dimasa yang akan datang. Penilaian kondisi atau prospek bidang usaha yang dibiayai hendaknya benar-benar memiliki prospek yang baik, sehingga kemungkinan kredit tersebut bermasalah relatif kecil.

\section{e. Collateral}

Merupakan jaminan yang diberikan calon nasabah baik yang bersifat fisik maupun non fisik. Jaminan hendaknya melebihi jumlah kredit yang diberikan. Jaminan juga harus diteliti keabsahan dan kesempurnannya, sehingga jika terjadi suatu masalah, maka jaminan yang dititipkan akan dapat dipergunakan secepat mungkin.

\subsection{Kredit Pertanian}

Pengertian kredit berdasarkan Undang-undang Perbankan No.7 tahun 1992 tentang pokok perbankan adalah penyediaan uang atau tagihan yang dapat dipersamakan dengan berdasarkan persetujuan atau kesepakatan pinjam meminjam antara pihak bank dengan pihak lain yang mewajibkan pihak peminjam melunasi hutangnya setelah jangka waktu tertentu dengan jumlah bunga, imbalan atau pembagian hasil keuntungan.

Peningkatan produksi dapat dicapai salah satunya yaitu adanya penambahan input yang diikuti dengan penambahan modal, sedangkan modal dapat bersumber dari modal sendiri atau dari modal pinjaman (kredit). Jenis kredit berdasarkan kepentingan dibagi menjadi dua yaitu kredit konsumsi dan kredit produksi. Kredit konsumsi diberikan kepada peminjam yang kekurangan dana untuk membiayai konsumsi keluarga. Sedangkan kredit produksi yaitu kredit yang diberikan kepada peminjam untuk membiayai kegiatan usaha yang bersifat produktif.

Menurut Ashari (2006), sektor pertanian pada dasarnya memerlukan faktor-faktor produksi yaitu tanah, tenaga kerja, modal dan pengelolaan manajemen. Tujuan dari kredit pertanian, khususnya kredit program yaitu untuk melindungi golongan ekonomi lemah. Dimana kredit program bertujuan ganda yaitu 
selain peningkatan produksi melalui introduksi teknologi dalam rangka swasembada pangan juga ditujukan untuk meningkatkan pendapatan petani dan mengurangi kemiskinan.

\subsection{Lembaga Keuangan Mikro Agribisnis (LKM-A) PUAP}

Menurut Suwandhi dalam Hermawan dan Harmi (2012) di Indonesia, LKM dapat dibedakan menjadi beberapa bentuk, yaitu : formal, semi formal dan non formal. LKM formal merupakan LKM yang keberadaannya telah mempunyai payung hukum (Undang-undang), sementara perkembangannya, LKM semi formal dapat ditingkatkan statusnya menjadi LKM formal. Sedangkan LKM non-formal keberadaannya berdasarkan inisiatif masyarakat sendiri atau ditumbuhkan oleh LSM dan beberapa Dinas Teknis.

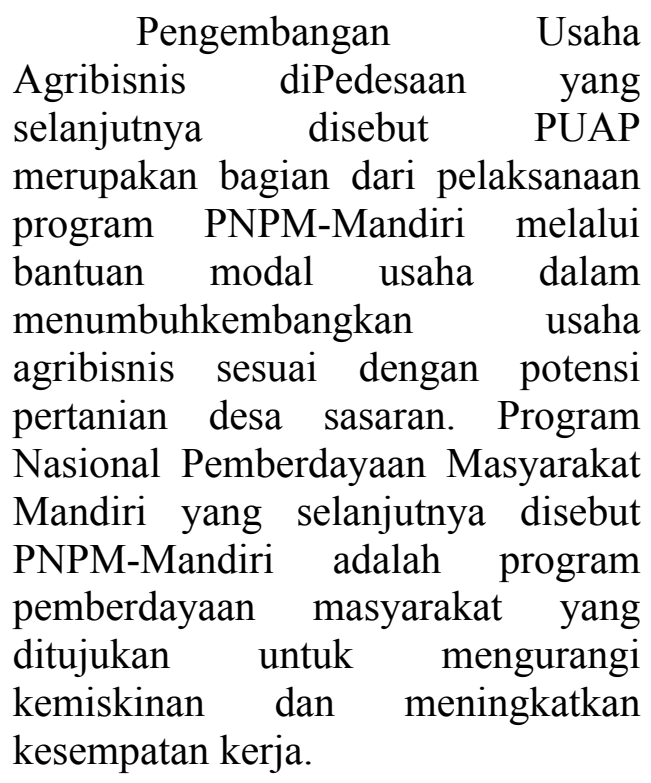

Pengembangan Usaha Agribisnis Pedesaan (PUAP) pada intinya merupakan upaya untuk memberdayakan masyarakat agar mampu menolong dirinya sendiri melalui peningkatan kemampuan untuk mengidentifikasi dan memanfaatkan peluang usaha agribisnis di pedesaan. Salah satu entry point yang dilakukan dalam PUAP adalah memberikan bantuan penguatan modal usaha agribisnis sebesar 100 juta rupiah per desa yang akan diberikan kepada masyarakat melalui Gabungan Kelompok Tani (Gapoktan).

Gabungan Kelompok Tani (Gapoktan) merupakan kelembagaan tani pelaksana PUAP untuk penyaluran bantuan modal usaha bagi anggota. Untuk mencapai hasil yang maksimal dalam pelaksanaan PUAP, Gapoktan didampingi oleh tenaga Penyuluh Pendamping dan Penyelia Mitra Tani (PMT). Melalui pelaksanaan PUAP diharapkan Gapoktan dapat menjadi kelembagaan ekonomi yang dimiliki dan dikelola petani.

Untuk mencapai tujuan PUAP, yaitu mengurangi tingkat kemiskinan dan pengangguran di pedesaan, PUAP dilaksanakan secara terintegrasi dengan kegiatan Kementrian Pertanian maupun Kementrian/Lembaga lain dibawah payung program PNPM-Mandiri. Adapun tujuan PUAP yaitu :

a. Mengurangi kemiskinan dan pengangguran melalui penumbuhan dan pengembangan kegiatan usaha agribisnis dipedesaan sesuai dengan potensi wilayah.

b. Meningkatkan kemampuan pelaku usaha agribisnis, Pengurus Gapoktan, Penyuluh dan Penyelia Mitra Tani.

c. Memberdayakan kelembagaan petani dan ekonomi pedesaan untuk pengembangan kegiatan usaha agribisnis.

d. Meningkatkan fungsi kelembagaan ekonomi petani 
menjadi jejaring atau mitra lembaga keuangan dalam rangka akses ke permodalan. (Permentan No.04/Permentan/OT.140/2/201).

Sedangkan sasaran dari PUAP yaitu :

a. Berkembangnya usaha agribisnis didesa terutama desa miskin yang terjangkau sesuai dengan potensi pertanian desa.

b. Berkembangnya

Gapoktan/Poktan yang dimiliki dan dikelola oleh petani untuk menjadi kelembagaan ekonomi.

c. Meningkatnya kesejahteraan rumah tangga tani miskin, petani/peternak (pemilik dan/atau penggarap) skala kecil, buruh tani.

d. Berkembangnya usaha agribisnis petani yang mempunyai siklus usaha harian, mingguan, maupun musiman.

(Permentan

No.04/Permentan/OT.140/2/201).

PUAP yang dikelola secara mandiri oleh LKM-A Gapoktan akan memberikan kesempatan kepada petani dalam beberapa hal, yaitu pembelian input produksi (benih, pupuk dan pestisida), pembelian alat dan mesin pertanian (cangkul, bajak, garu, traktor, pompa air dan power thresher). Bahkan, pada pembelian alat yang berkategori mahal menurut ukuran petani, dapat dilakukan secara kolektif dengan dikoordinasikan oleh Gapoktan. Petani juga berkesempatan diversifikasi berbagai komoditas dan atau ternak dengan tanaman yang bernilai tinggi (high value commodities).

III. METODOLOGI PENELITIAN

3.1. Lokasi dan Waktu Penelitian
Adapun yang menjadi lokasi penelitian adalah Kecamatan Kemuning dan Kecamatan Kempas Kabupaten Indragiri Hilir dengan alasan menurut BPS Kabupaten Inhil Tahun 2013, Kecamatan Kemuning merupakan daerah dataran tinggi dengan hasil pertaniannya sebagian besar pada sektor perkebunan, sedangkan Kecamatan Kempas merupakan daerah dataran rendah (rawa) dengan hasil pertaniannya tanaman pangan, palawija, hortikultura, dan lain-lain. Pengumpulan data dilakukan selama satu bulan, yaitu bulan Mei 2014 . Selanjutnya pengolahan data dan penulisan hasil laporan dilakukan selama tiga bulan, yaitu pada bulan Agustus sampai dengan bulan Oktober 2014.

\subsection{Metode Pengambilan Sampel}

Populasi adalah keseluruhan dari subyek penelitian. Populasi merupakan kumpulan pengukuran atau data pengamatan yang dilakukan terhadap orang, benda atau tempat. Sedangkan sampel adalah sebagian wakil populasi yang diteliti.

Penentuan sampel dilakukan dengan metode stratified random sampling dengan melihat Non Performing Loan anggota Poktan tersebut, dengan membagi pada 3 kelompok yaitu : kelompok I $($ rendah $)=0 \%-33 \%$, kelompok II $($ sedang $)=34 \%-67 \%$, kelompok III $($ tinggi $)=68 \%-100 \%$. Sehingga jumlah sampel secara keseluruhan adalah 197 orang.

\subsection{Teknik Pengumpulan Data}

Data dalam penelitian ini berupa data primer dan data 
sekunder, data tersebut diperoleh melalui:

1. Wawancara terstruktur, dilakukan terhadap pengurus Gapoktan, pengurus kelompok tani dan anggota kelompok tani yang menerima BLM-PUAP menggunakan kuesioner. Secara teknis pertanyaan yang diajukan peneliti kepada informan berdasarkan panduan wawancara atau butir pertanyaan yang sudah disiapkan, dalam kuesioner untuk menggali informasi yang terkait dengan permasalahan penelitian. Selama wawancara, peneliti mendengarkan secara teliti dan mencatat apa yang dikemukakan oleh informan terkait sesuai pedoman wawancara.

2. Observasi lapangan, yaitu dilakukan dengan mengamati fenomena-fenomena di lapangan terhadap objek penelitian untuk melakukan corss check terhadap jawaban informan. Kegiatan observasi lapangan berupa survey langsung terhadap kondisi kelompok tani yang dijadikan sampel, serta untuk melihat secara langsung kegiatankegiatan dalam proses penyaluran kredit ke petani. Selain itu dilakukan survey terhadap anggota kelompok tani penerima BLM-PUAP untuk menggali informasi mengenai faktor-faktor pengembalian kredit.

3. Studi kepustakaan dan dokumentasi, yaitu dengan mempelajari berbagai bahan bacaan, seperti bahan teoritik, makalah ilmiah, dokumen dan laporan, termasuk berbagai peraturan dan kebijakan yang berkaitan dengan masalah penelitian dari berbagai sumber resmi seperti Dinas Pertanian, Badan Pelaksana Penyuluhan dan Ketahanan Pangan, serta BPS, dll.

\subsection{Teknik Analisis Data}

\section{Regresi Linear Berganda}

Analisis yang digunakan untuk mengetahui faktor-faktor pengembalian kredit program BLMPUAP yang dilihat dari sisi anggota kelompok tani ialah model regresi linear berganda. Analisis regresi linear berganda digunakan untuk mengukur pengaruh antara lebih dari satu variabel prediktor (variabel bebas) terhadap variabel terikat. Pada penelitian ini variabel terikat $\mathrm{Y}$ adalah besarnya tunggakan kredit yang diukur dalam bentuk persentase (\%), sedangkan variabel bebasnya adalah usia, jenis kelamin, tingkat pendidikan formal, jumlah tanggungan keluarga, pengalaman usaha, jarak tempat tinggal dengan kantor BLM-PUAP, omset usaha, jumlah pinjaman, anggota kelompok lahir di daerah yang sama dengan daerah penelitian, pernah mendapat sangsi dari kelompok, pengaruh orang lain yang tidak membayar kredit, sikap petani tidak mau bayar kredit karena anggapan BLM-PUAP adalah dana hibah dan pekerjaan utama.

Sampel yang ditanya adalah anggota kelompok tani. Estimasi model regresi pada penelitian ini adalah :

$$
\begin{gathered}
\mathrm{Y}=\alpha+\beta_{1} \mathrm{X}_{1}+\beta_{2} \mathrm{X}_{2}+\beta_{3} \mathrm{X}_{3}+\ldots . .+ \\
\beta_{13} \mathrm{X}_{13}+\varepsilon
\end{gathered}
$$

Keterangan :

: Besar tunggakan kredit anggota $(\%)$ 


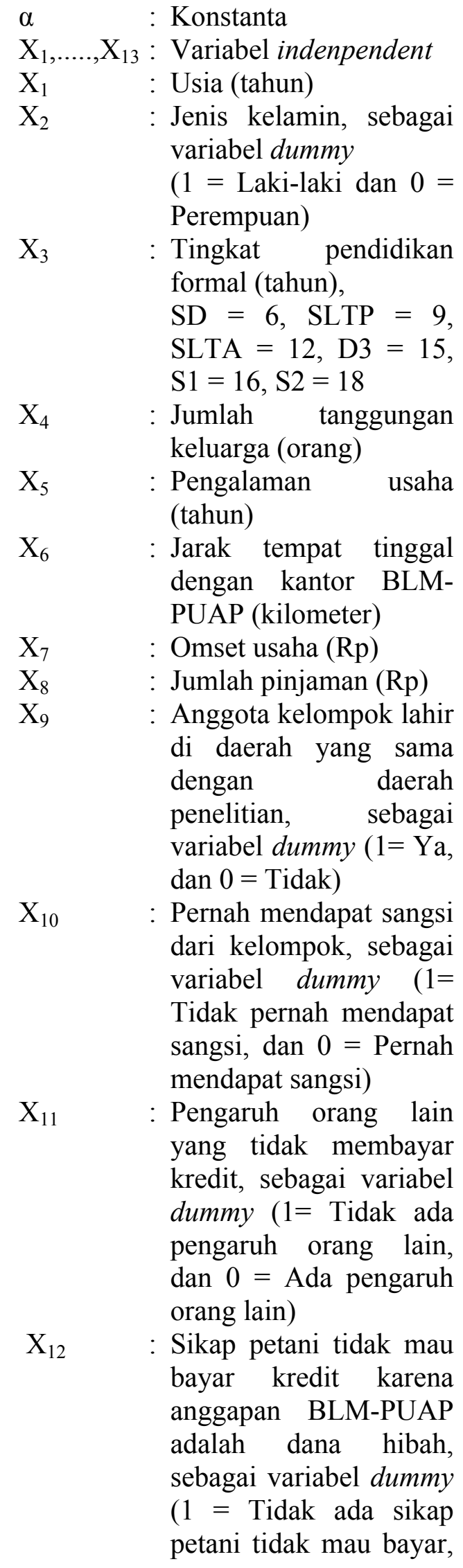

\author{
dan $0=$ Ada sikap \\ petani tidak mau bayar) \\ $\mathrm{X}_{13} \quad$ : Pekerjaa utama, sebagai \\ variabel dummy ( $1=$ \\ Perkebunan, dan $0=$ \\ Selain perkebunan) \\ $\beta_{1}, \ldots . ., \beta_{13}$ : Koefisien variabel \\ independent
}

\section{HASIL DAN PEMBAHASAN}

\subsection{Uji Asumsi Klasik}

\section{a. Asumsi Multicollinearity}

Asumsi multicollinearity ini untuk menguji apakah dalam model regresi ditemukan adanya korelasi antar variabel independen. Model regresi yang baik seharusnya tidak terjadi korelasi diantara variabel independen. Multicollinearity dapat dideteksi dengan melihat besar VIF. Apabila VIF > 5 maka dalam model regresi terjadi multicollinearity. Hasil uji asumsi multicollinearity dalam penelitian ini dapat disajikan pada Tabel 1. 
Tabel 1. Hasil Uji Asumsi Multicollinearity

\begin{tabular}{ccc}
\hline Variabel & VIF & Keterangan \\
\hline X1 & 0,307 & Tidak ada multicollinearity \\
X2 & 0,406 & Tidak ada multicollinearity \\
X3 & 0,059 & Tidak ada multicollinearity \\
X4 & 0,120 & Tidak ada multicollinearity \\
X5 & 0,299 & Tidak ada multicollinearity \\
X6 & 0,000 & Tidak ada multicollinearity \\
X7 & 0,150 & Tidak ada multicollinearity \\
X8 & 0,331 & Tidak ada multicollinearity \\
X9 & 0,295 & Tidak ada multicollinearity \\
X10 & 0,314 & Tidak ada multicollinearity \\
X11 & 0,019 & Tidak ada multicollinearity \\
X12 & 0,000 & Tidak ada multicollinearity \\
X13 & 0,001 & Tidak ada multicollinearity \\
\hline
\end{tabular}

Tabel 1 menunjukkan bahwa besar VIF $<5$, sehingga dapat disimpulkan bahwa dalam model regresi anggota kelompok tani tidak terjadi multicollinearity.

\section{b. Asumsi Heterokedastisitas}

Asumsi heterokedastisitas ini untuk mengetahui apakah dalam suatu model regresi terjadi ketidaksamaan varians dari residual dari suatu pengamatan ke pengamatan lain. Heterokedastisitas ini mengakibatkan hasil regresi tidak efisien, tetapi hasilnya masih tetap tidak bias dan konsisten. Pengujian dilakukan dengan menggunakan uji Gletsjer. Apabila nilai signifikansi $>$ $\alpha$, maka dalam model terjadi homokedastisitas dan jika nilai signifikansi $<\alpha$, maka dalam model terjadi heterokedastisitas. Hasil uji asumsi heterokedastisitas tersaji pada Tabel 2.

Tabel 2. Hasil Uji Asumsi Heterokedastisitas

\begin{tabular}{ccc}
\hline No & Variabel & Signifikansi \\
\hline 1 & X1 & 0,478 \\
2 & X2 & 0,414 \\
3 & X3 & 0,057 \\
4 & X4 & 0,279 \\
5 & X5 & 0,965 \\
6 & X6 & 0,869 \\
7 & X7 & 0,644 \\
8 & X8 & 0,066 \\
9 & X9 & 0,862 \\
11 & X11 & 0,449 \\
12 & X12 & 0,705 \\
13 & X13 & 0,189 \\
\hline
\end{tabular}


Tabel 2 memperlihatkan bahwa t statistik menunjukkan bahwa

tidak adanya pengaruh yang signifikan pada masing-masing variabel independen terhadap variabel dependen dimana variabel dependen yaitu $\mathrm{e}_{\mathrm{i}}$ atau error absolut, hal ini dapat dibuktikan dengan diperolehnya nilai signifikansi untuk masing-masing variabel yang lebih besar dari 5\% (sig > 0,05). Dari hasil tersebut dapat disimpulkan bahwa model regresi anggota kelompok tani tidak ada gejala heterokedastisitas.

\section{c. Asumsi Autokorelasi}

Uji autokorelasi digunakan untuk menguji apakah dalam sebuah model regresi ada korelasi antar anggota sampel. Untuk mengetahui ada tidaknya gejala autokorelasi pada model regresi anggota kelompok dilakukan dengan uji Run Test. Run Test sebagai bagian dari nonparametrik dapat pula digunakan untuk menguji apakah antar residual terdapat korelasi yang tinggi (Ghozali, 2011). Hasil uji Run Test sebesar 0,064. Jika asymp sig (2tailed) pada output runs test lebih besar dari 0,05 maka data tidak mengalami atau mengandung autokorelasi dan sebaliknya. Sehingga dapat disimpulkan bahwa model regresi pada anggota kelompok tidak terjadi autokorelasi antar variabel independen.

\subsection{Faktor-faktor yang Mempengaruhi Besar Tunggakan Kredit BLM- PUAP}

Analisis regresi pada dasarnya berkaitan dengan studi ketergantungan suatu variabel terikat (dependen) pada satu atau lebih variabel bebas atau penjelas (independen) dengan tujuan untuk mengetahui seberapa besar pengaruh variabel independen terhadap variabel dependen. Berdasarkan hasil pengujian diperoleh hasil yang tersaji pada Tabel 3.

Tabel 3. Hasil Pengolahan Faktor-faktor yang Mempengaruhi Besar Tunggakan Kredit BLM-PUAP

\begin{tabular}{lrrl}
\hline \multicolumn{1}{c}{ Variabel } & Koef.Regresi & \multicolumn{1}{c}{$\mathrm{t}_{\text {hitung }}$} & Sig. \\
\hline Konstanta & 1,128 & 6,794 & 0,000 \\
Usia & $-0,003$ & $-1,025$ & 0,307 \\
Jenis kelamin & $-0,054$ & $-0,666$ & 0,506 \\
Tingkat pendidikan formal & $-0,015$ & $-1,907$ & 0,059 \\
Jumlah tanggungan keluarga & 0,027 & 1,568 & 0,120 \\
Pengalaman usaha & $-0,006$ & $-1,042$ & 0,299 \\
Jarak tempat tinggal dg kantor BLM-PUAP & $-0,099$ & $-4,208$ & $0,000^{*}$ \\
Omset usaha & $0,0000000-388$ & $-1,448$ & 0,150 \\
Jumlah pinjaman & 0,0000000662 & 0,976 & 0,331 \\
Anggota lahir di daerah penelitian & $-0,039$ & $-1,052$ & 0,295 \\
Pernah mendapat sangsi & 0,009 & 0,236 & 0,814 \\
Pengaruh orang lain & $-0,089$ & $-2,376$ & $0,019^{* *}$ \\
Sikap petani tidak mau bayar kredit & $-0,138$ & $-3,644$ & $0,000^{*}$ \\
Pekerjaan Utama & $-0,140$ & $-3,298$ & $0,001^{*}$ \\
\hline
\end{tabular}

Signifikan * = taraf nyata $1 \%$

Signifikan $* *=$ taraf nyata $5 \%$ 
Analisis linear berganda dalam penelitian ini digunakan untuk mengetahui seberapa besar pengaruh antara variabel usia, jenis kelamin, jumlah tanggungan keluarga, pengalaman usaha, jarak tempat tinggal dengan kantor BLMPUAP,omset usaha, jumlah pinjaman, dummy anggota kelompok lahir di daerah yang sama dengan daerah penelitian, dummy pernah mendapat sangsi dari kelompok, dummy pengaruh orang lain yang tidak membayar kredit, dummy pengaruh sikap petani tidak mau bayar kredit karena anggapan BLMPUAP adalah dana hibah terhadap besarnya tunggakan kredit.

Berdasarkan Tabel 3 dapat dilihat bahwa hanya 4 variabel yang berpengaruh nyata terhadap besar tunggakan kredit BLM-PUAP di Kecamatan Kemuning Kabupaten Indragiri Hilir dengan taraf nyata 1 persen dan 5 persen.

\section{a. Variabel Jarak Tempat Tinggal dengan Kantor BLM-PUAP}

Hasil uji menunjukkan bahwa variabel jarak tempat tinggal dengan kantor BLM-PUAP berpengaruh negatif dan signifikan terhadap besar tunggakan kredit, dengan koefesien regresi sebesar -0,099 serta hasil uji $\mathrm{t}$ menunjukkan nilai sig. $<\alpha$ yaitu $0,000<0,01$. Pengujian variabel jarak tempat tinggal dengan kantor BLM-PUAP berpengaruh nyata terhadap besarnya tunggakan kredit pada program dana BLM-PUAP.

Hasil penelitian menunjukkan bahwa besar tunggakan kredit yang paling besar berada pada responden dengan jarak yang tidak terlalu jauh dengan kantor BLM-PUAP yaitu jarak 0-1 kilometer yaitu sebanyak
59 responden, dimana 9 responden berada pada tunggakan 0 sampai 33 persen, 24 responden berada pada tunggakan 34 sampai 67 persen dan 26 responden berada pada tunggakan 68 sampai 100 persen.

\section{b. Variabel Pengaruh Orang Lain yang Tidak Membayar}

Hasil uji menunjukkan bahwa variabel pengaruh orang lain yang tidak membayar kredit berpengaruh negatif dan signifikan terhadap besar tunggakan kredit, dengan koefesien regresi sebesar -0,089 serta hasil uji t menunjukkan nilai sig. $<\alpha$ yaitu $0,019<0,05$. Pengujian variabel pengaruh orang lain yang tidak membayar kredit berpengaruh nyata terhadap besarnya tunggakan kredit pada program dana BLM-PUAP.

Dalam penelitian menunjukkan bahwa variabel adanya pengaruh orang lain berada pada proporsi terbesar tunggakan kredit yaitu sebanyak 80 responden. Hal ini dikarenakan dengan latar pendidikan responden yang rendah sehingga mudah terpengaruh oleh orang lain. Dimana mendengar anggota lain yang sebenarnya mampu untuk membayar kreditnya tetapi tidak membayar kreditnya, sehingga anggota yang lainnya juga enggan membayar kreditnya walaupun ia mampu untuk membayarnya.

\section{c. Variabel Sikap Petani Tidak Mau Bayar Kredit}

Hasil uji menunjukkan bahwa variabel sikap petani tidak mau bayar kredit karena anggapan dana BLMPUAP adalah dana hibah berpengaruh negatif dan signifikan terhadap besar tunggakan kredit, dengan koefesien regresi sebesar $-0,138$ serta hasil uji t menunjukkan 
nilai sig. $<\alpha$ yaitu $0,000<0,01$. Pengujian terhadap variabel sikap petani tidak mau bayar kredit berpengaruh nyata terhadap besarnya tunggakan kredit pada program dana BLM-PUAP.

Variabel sikap petani tidak mau bayar kredit karena anggapan bahwa program dana BLM-PUAP merupakan dana hibah yang diberikan pemerintah secara cumacuma kepada mereka sangat erat kaitannya dengan tingkat pendidikan responden itu sendiri. Hasil penelitian menunjukkan bahwa komposisi terbesar adanya sikap petani menganggap dana BLMPUAP merupakan dana hibah yaitu pada tingkat pendidikan SD yaitu sebanyak 30 responden. Dengan tingkat pendidikan yang rendah maka pengetahuan dan informasi yang diterima akan lambat ditangkap. Adanya sikap responden yang tidak mau membayar kredit disebabkan pengurus kurang mengenal watak dan karakter anggotanya karena kurang memiliki informasi yang lengkap dan ditambah lagi tidak dilakukannya seleksi yang ketat terhadap anggota sehingga terjadinya salah pilih anggota.

\section{d. Pekerjaan Utama}

variabel pekerjaan utama berpengaruh negatif dan signifikan terhadap besar tunggakan kredit, dengan koefesien regresi sebesar 0,140 serta hasil uji t menunjukkan nilai sig. $<\alpha$ yaitu $0,001<0,01$. Pengujian terhadap variabel sikap petani tidak mau bayar kredit berpengaruh nyata terhadap besarnya tunggakan kredit pada program dana BLM-PUAP.
Hasil penelitian menunjukkan bahwa pekerjaan responden selain perkebunan berada pada tunggakan kredit terbesar yaitu sebanyak 92 responden, sedangkan responden yang bekerja pada sektor perkebunan sebanyak 46 orang. Hal ini mengindikasikan bahwa semakin banyak responden yang bekerja pada sektor perkebunan maka tunggakan kredit dapat semakin menurun. Responden yang bekerja di sektor perkebunan akan memperoleh pendapatan bulanan sehingga mereka bisa membayar cicilan kredit tiap bulannya, berbeda dengan responden yang bekerja selain sektor perkebunan, dimana mereka mayoritas tidak mempunyai pekerjaan sampingan sehingga tidak mempunyai pendapatan bulanan dan hanya memperoleh pendapatan yang mengandalkan hasil panen yaitu 3 bulan sekali sehingga mengalami kesulitan membayar cicilan kredit tiap bulannya. Walaupun pekerjaan utama telah sesuai dengan RUB tetapi salah pilih anggota tetap terjadi, hal ini karena watak anggota itu sendiri hal ini menunjukkan bahwa pengurus kurang mengenal anggotanya dimana tidak memiliki informasi pribadi yang lengkap tentang anggota sebelum masuk dalam kelompok. Kemudian tidak dilakukannya penyeleksian yang kurang maksimal sehingga berakibat terjadi salah pilih anggota yang tidak diinginkan.

Pengujian uji $F$ bertujuan untuk mengetahui pengaruh variabel bebas terhadap variabel besar tunggakan kredit secara bersamasama. Variabel bebas akan terbukti berpengaruh secara signifikan terhadap variabel terikat jika nilai statistik signifikansi lebih kecil dari 
tingkat signifikansi yang digunakan yaitu persen (sig. $<\alpha$ ). Sebaliknya jika nilai statistik signifikansi lebih besar dari tingkat signifikansi (sig.> a) maka variabel bebas tidak berpengaruh secara signifikan terhadap variabel terikat.

Hasil nilai $F_{\text {hitung }}$ adalah 8,246 sedangkan nilai statistik signifikansi adalah 0,000. Jadi nilai statistik signifikansi lebih kecil dari tingkat signifikansi (sig. $<\alpha$ ) yaitu $0,000<$ 0,05 . Hal ini menunjukkan bahwa variabel independent secara bersamasama berpengaruh positif dan signifikan terhadap variabel dependent pada tingkat signifikan 5 persen.

\section{PENUTUP}

\subsection{Kesimpulan}

Hasil

Pengujian

menggunakan regresi berganda menghasilkan faktor-faktor yang berpengaruh nyata terhadap besar tunggakan kredit adalah variabel variabel jarak tempat tinggal dengan Kantor BLM-PUAP, variabel pengaruh orang lain yang tidak membayar kredit, variabel sikap petani tidak mau bayar karena menganggap dana BLM-PUAP merupakan dana hibah dan pekerjaan utama. Sedangkan faktor-faktor yang berpengaruh nyata terhadap persentase besar tunggakan kredit dilihat dari sisi kelompok yaitu variabel persentase jenis kelamin perempuan, variabel seleksi anggota dan variabel kenal anggota.

\subsection{Saran}

1. Dana BLM-PUAP hendaknya didistribusikan pada orang yang berpendidikan agar lebih memahami tujuan BLM-PUAP dan meminimalisir terjadinya tunggakan kredit.

2. Diharapkan adanya kegiatan penyuluhan yang rutin dilaksanakan mengenai penjelasan prosedur program BLM-PUAP dan kontrak yang jelas sehingga tidak terjadi kesalahpahaman.

3. Pengurus kelompok agar dapat melakukan penyeleksian anggota secara ketat sehingga tidak terjadi salah pilih anggota dan diharapkan pengurus lebih sering melakukan pengawasan terhadap anggota kemudian menerapkan sangsi yang tegas kepada anggota yang sengaja menunda-nunda pembayaran kredit tanpa memberikan alasan yang jelas sehingga dapat memberikan efek jera kepada anggota.

\section{DAFTAR PUSTAKA}

Anggraeni Noviani. 2011. Analisis Faktor Penyebab Moral Hazard Pada Program PUAP (Pengembangan Usaha Agribisnis Pedesaan) Wilayah Utara Kabupaten Cianjur. Skripsi. Institut Pertanian Bogor. Bogor.

Anita Andi. 2011. Analisis Pendapatan Penerima Bantuan Langsung Masyarakat Pengembangan Usaha Agribisnis Pedesaan (BLM-PUAP) di Kabupaten Baritokuala. Tesis. Universitas Lambung Mangkurat. Banjar Baru.

Apriyanti Liyana. 2011. Analisis Program Pemberdayaan Masyarakat Dalam 
Penanggulangan Kemiskinan Kota Semarang. Skripsi. Universitas Diponegoro. Semarang.

Ariyati Farida. 2011. Pemberdayaan Masyarakat Berbasis Program Pengembangan Usaha Agribisnis Pedesaan (PUAP). Jurnal. Nomor 2, JuliDesember 2011.

Ashari. 2009. Optimalisasi Kebijakan Kredit Program Sektor Pertanian di Indonesia. Jurnal. Pusat Penelitian Sosial Ekonomi dan Kebijakan Pertanian. Bogor.
BPS. 2013. Badan Pusat Statistik. Indragiri Hilir.

Erani A.Y. 2006. Ekonomi Kelembagaan. Bayumedia Publishing. Malang.

Ghozali Imam. 2011. Aplikasi Analisis Multivariate dengan Program IBM SPSS19. Badan Penerbit Universitas Diponegoro. Semarang.

Gujarati DN. 2006. Dasar-dasar Ekonometrika. Penerbit Erlangga. Jakarta. 